DOI 10.37882/2500-3682.2021.02.28

\title{
ПОТЕНЦИАЛЬНОСТЬ ЛИМИНАЛЬНОСТИ В ПЕРИОД КОВИДА
}

\section{MORALITY DURING THE LIMINAL QUARANTINE PERIOD}

L. Fusu

Summary: In the work, the potential of the preliminal period, preceding the forced isolation of modern society and individual individuals in particular, against the background of the ongoing epidemic, is subjected to philosophical understanding. The article analyzes various preliminal states that are situationally different from the space outside the liminal period. It is determined that the current unexpected events or shocks disrupt our usual rhythm of life, take us out of our comfort zone and make us ask serious questions about what is important and what is worth doing. Therefore, it is not surprising that during the current pandemic, many people are forced to rethink their own careers and life orientations.

Keywords: liminality, potentiality, restriction of freedom, covid, isolation, pandemic.
$\Pi$ родолжающаяся пандемия коронавируса стала серьёзным вызовом для всего человечества в новом тысячелетии. По масштабу воздействия ее можно сравнить с эпохальными событиями XX века, когда человечество, затронутое ими, было шокировано и с тревогой вглядывалось в будущее. Постепенно, а кому-то внезапно пришло понимание неизбежности грядущих перемен. Наступление фундаментальных сдвигов в общественном укладе и мышлении человека порождают пограничные состояния возникающие при этом, затрагивают массовое сознание и вызывают различного рода реакции нехарактерные для обычной действительности. Отчасти похожие состояния, опираясь на обширный эмпирический материал изучал французский антрополог Арнольд ван Генеп больше ста лет назад. С тех пор, безусловно многое изменилось, однако массовое сознание в отличии от индивидуальной психологии человека меняется мало. В своей относительно поздней работе 3. Фрейд утверждал «Миром правят жажда власти, секс и чувство голода» это определение в массовом сознании за последние сто лет ничуть не изменились. Так было прежде, так происходит и в настоящее время.

Генеп считал, что любые процессы, происходящие в переходных состояниях, определяются тремя основными фазами:

1. отчуждение;

2. лиминальность;

3. ассоциация.

Первая фаза - отчуждение - содержит в себе изоля-
Фусу Лариса Ивановна

К.м.н., психоаналитик, ректор,

Институт психологии и психоанализа на Чистых прудах

florayy@mail.ru

Аннотация: В работе подвергается философскому осмыслению потенциальность предлиминального периода, предшествующего вынужденной изоляции современного общества и отдельных индивидуумов, в частности, на фоне продолжающейся эпидемии. В статье проводится анализ различных предлиминальных состояний, ситуационно отличающихся от пространства за пределами лиминального периода. Определено, что нынешнее неожиданные события или потрясения нарушают наш привычный ритм жизни, выводят нас из зоны комфорта и заставляют задавать серьезные вопросы 0 том, что важно и что стоит делать. Поэтому неудивительно, что во время нынешней пандемии многие люди вынуждены переосмысливать собственную карьеру и жизненные ориентиры.

Ключевые слова: лиминальность, потенциальность, ограничение свободы, ковид, изоляция, пандемия.

цию конкретного индивидуума от привычной и характерной для его образа жизни социальной или культурной среды.

Вторая фаза - лиминальность - определяет состояние при котором инициатор находится в двойственной позиции, его нахождение в некоторой амбивалентной социальной зоне в состоянии неопределенности. Третья, заключительная фаза - инкорпорация - соответствует «повторной сегрегации» индивида: возвращению инициатора в общество, но в другом, обновленном социальном статусе.

Из всех вышеперечисленных фаз особый интерес для нас представляет первая потенциально предлиминальная фаза, во время которой индивид чаще всего внезапно проникает в состояние полной неопределенности социальной среды и начинает утрачивать ощущение той реальности, к которой он привык. Соответственно, процесс начинающегося перехода, по мнению Генепа, можно представить, как целостное единство всех трех условий: «предварительных», подразумевающих удаление-отделение от прежнего мира; «лиминал», обозначающий период транзитивности; и «постсознательный», связанный с церемонией включения в новый мир. Под «старым» и «новым» мы подразумеваем не только мелкие, но и масштабные культурные транспозиции. Т.Л. Карсон справедливо отмечает: «Для мыслителя своей эпохи, ван Генепа, это была рискованная, но блестящая теория. Для Генепа структурная обыденность и культурное разнообразие не являются взаимно отдаленными друг от друга поня- 
тиями, а сосуществуют и пересекаются друг с другом. Обыкновенные модели трансформируются в уникальные культурные явления. «Как переход, воспринимается сама Жизнь, a rites de transition - ритуалы перехода - колесницы, с помощью которых осуществляются глобальные преобразования» [Карсон, 3]. Генеп отмечает: «Для группы людей, как и для отдельных лиц, жизнь состоит из удаления, отчуждения и нового объединения, изменения формы и состояния, смерти и нового рождения. Жизнь - это действие и остановка, ожидание и остановка, и затем снова действие, но в другом направлении ... И постоянно возникают разные, все новые границы, которые необходимо преодолевать: между летом и зимой, сезонными, ежегодными, ежемесячными и даже ежедневными; между рождением, юностью, зрелостью и старость и, самое главное, грань между смертью и жизнью после смерти для тех, кто в нее верит» $[2,18]$. Виктор Тернер определил лиминальную фазу как «межструктурную ситуацию» между «разными позиционными структурами».

Какие же условия определяют возникновение потенциальной прелиминальную фазы, которая служит порогом, отделяющим разные стадии жизни друг от друга. По мнению Тернера, временная изоляция человека от стабильной социальной структуры не только придает ему амбивалентный социальный статус, но и освобождает от любых законов, поведенческих норм и правил. Действие как «предыдущего», так и «будущего» статуса приостанавливается, индивид находится в состоянии отчуждения и неопределенности, в состоянии ожидания реализации реконструированных и обновленных культурных моделей, и парадигм» [Тернер,126].

Развитию этих явлений в общественном сознании, применительно к сложившейся ситуации пандемии ковид, порождены на наш взгляд двумя основными укоренившимися за длительное время парадигмами. Во-первых, общественное сознание сформировавшееся за последние сто лет уверовало в устойчивое и победоносное движение научной мысли подкрепленной техническим прогрессом над большим количеством смертельных ранее заболеваний. Во-вторых, устойчивое снижение в обществе реального уровня образования, организуемое со стороны властных структур, уменьшает количество трезво и критически мыслящих индивидуумов, увеличивая тем самым количество малограмотных и легко подвергающимся манипуляциям масс. Широкое распространение информационных коммуникационных технологий позволяет более легко и быстро манипулировать общественным сознанием опираясь на постулаты Фрейда и не прибегая к грубой силе. Поскольку лиминальность выявляет не только изоляцию от устойчивых структур, но и возможность образования альтернативных структур, замечает Р. Палмер: «Человек, который переходит в лиминальную фазу, имеет индивидуальный потенциал, но он оказывается в разломе, существующем между мирами, т.е. он в равной степени является концептуальной средой для альтернативных структур, существующих «там» и «здесь» [Палмер,8].

Неожиданно и почти внезапно возникающая ситуация локальной эпидемиологической ситуации, перерастающей в пандемию вызывает много вопросов. Сознание обычного человека, воспринимающего происходящее на начальном этапе, отстранено, практически не воспринимает происходящее. По мере того как развиваются эпидемия и как эти события ретранслируют средства массовой информации в индивидууме постепенно накапливается информация, которая на определенном этапе достигает некоторой критической массы. Однако так происходит не у всех. Общественное сознание, к которому относится психология которой руководствуется большинство людей, увы, неспособно к критическому осмыслению информации и самоанализу. Чаще всего именно информационные, а не реальные события становятся отправными точками, формирующими начало предлиминального периода. Мы полагаем, что этот вопрос апеллирует к общей парадигме проблемы философских разногласий об индивидуальной свободе человека и его личном «Я». Что представляют собой учения Шопенгауэра, Кьеркегора и Ницше, обращенные против господствующего насилия, террора и технократии к свободе деятельности, творческой воле и защите индивидуальной мысли, кроме стремления к альтернативе? Жизненная философия воли Шопенгауэра, как и ницшеанская философия стремящейся к воле агрессии, ценна не только потому, что она отделяет жизнь от насилия, но также потому, что она допускает существование жизни без подчинения насилию. Другими словами, если реально существующий мир является заданным условием потенциального лиминального состояния, т. е. если оно приводит к удалению индивида из его устойчивых структур, то альтернативный мир действует как продукт постлиминального состояния, которое формируется в результате трансформации. Однако познать, даже интуитивно, этот внешний и во многом мистический космос с исторической или парадигматической точки зрения не только чрезвычайно сложно, но и практически невозможно. Как условность, она существует только на уровне сознания субъекта, ее осмысление возможно только вне воли субъекта; очень сильная воля, которая борется с «рабским менталитетом», значима для исторического или реального контекста.

Исходя из этого, можно сделать вывод, что все три фазы перехода - пред-лиминала, лиминала и постлиминала, формируются в общем ходе как синхронного, так и внутриструктурного, и диахронические, или культурно-исторические, модели и даны для создания позитивных альтернатив. Позитивная альтернатива - это продукт творческой воли, ценный синтез воображения и творчества, граничащий с реальными, стабильными, 
историческими и культурными структурами и в результате сильнейшего опыта достигающий желаемой трансформации.

Но действительно ли сейчас подходящее время? Даже для тех из нас, кому посчастливилось не заболеть, кто ухаживает за другими больными или пытается свести концы с концами, пандемия усилила неопределенность и застала нас врасплох - психологически, финансово и инфраструктурно. Ситуация кажется угрожающей. И, как показали психологи, угрожающие ситуации побуждают нас вести себя консервативно - в противоположность тому, что требуется при рассмотрении вопроса о смене жизненных установок и приоритетов. Трудно полностью погрузиться в переосмысление собственной жизни, если вы чувствуете отвращение к риску или беспокоитесь о своих перспективах.

Отличительной чертой потенциально наступающего процесса смены жизненных установок является эмоциональное переживание «лиминальности», то есть существования между прошлым, которое явно ушло, и будущим, которое все еще неопределенно. Лиминальность может быть неприятным эмоциональным состоянием. Люди, проходящие через него, чувствуют себя не пришвартованными, теряют ориентацию и колеблются между «удержанием» и «отпусканием». Этот чреватый опасностями этап является необходимой частью путешествия, потому что он позволяет вам обрабатывать множество сложных эмоций и противоречивых желаний, и в конечном счете предотвращает вас от преждевременного закрытия и упущения лучших вариантов, которые все еще лежат впереди.

Нынешний кризис, вероятно, продлевает это промежуточное состояние для многих из нас. Хотя временами это вызывает разочарование, у государства есть свои преимущества. Неврологические исследования показывают, что использование лиминального времени для выполнения этого "внутреннего дела" может быть более полезным, чем вовлечение в шквал напряженных усилий по самосовершенствованию. Время простоя имеет решающее значение не только для пополнения запасов внимания и мотивации мозга, но и для поддержания когнитивных процессов, которые позволяют нам полностью развить нашу человечность. Это то, как мы консолидируем воспоминания, интегрируем то, что мы узна- ли, планируем будущее, поддерживаем наш моральный компас и строим наше чувство самих себя.

Саморефлексия, как это ни парадоксально, - это практика, которая лучше всего питается разговорами вслух в социальных обменах с родственными душами, которые отвечают, сочувствуют, сочувствуют, спрашивают, читают язык вашего тела и делятся своим собственным опытом. Одна из причин, по которой потенциальные карьеристы так выигрывают от посещения курсов, заключается в том, что их сокурсники представляют собой готовое сообщество родственных душ, с которыми можно поговорить. Простой акт создания и рассказа истории о том, что вы хотите сделать или почему вы хотите перемен, может прояснить ваше мышление и продвинуть вас вперед, публично обязав вас сделать изменения.

Таким образом, потенциальная предлиминальная фаза - это промежуточное, преходящее и амбивалентное состояние «ни там, ни здесь», в недрах которого индивид уходит от нормативного контекста и путем трансформации создает противоположный мир. В результате лиминальная фаза приобретает значение особой, несомненно, сакральной, пространственно-временной области. Процесс «мистического путешествия», «транзита», «таинственного движения» связан с символикой смерти и рождения, увядания и расцвета. «Обряды перехода» - это ритуал перехода одна модель существования к другой. Пограничное время, как и лиминальное пространство, выражает, с одной стороны, наиболее сложный процесс отделения индивида от упорядоченной хронологической системы и, с другой стороны, его присоединение к альтернативной, антихронологической системе.

Можно с большой степенью уверенности полагать, что литература - идеальное проявление предлиминальной фазы. Можно отметить, что с целью наглядной демонстрации наступающих пороговых процессов можно прибегать к рассмотрению литературных произведений, особенно драматического жанра, хотя считается, что пороговые процессы выражены в любом другом литературном жанре.

Можно с уверенность считать, что изучение литературных жанров в контексте предлиминальности сегодня является одной из самых серьезных методологических технологий.

\section{ЛИТЕРАТУРА}

1. Stenner, Paul, and David Kaposi. 2020. «Virus ante portas: the Covid-19 pandemic as a liminal hotspot.»

2. Timothy L. Carson, Liminal Reality and Transformational Power. - Lanham, New York Oxford, 1984.

3. Arnold Van Genep, The Rites of Passage. - London, 1960.

4. V. Turner, The Ritual Process. Structure and Anti-Structure. - New York, 1995.

5. Mihai I. Spariosu. The Wreath of Wild Olive. - New York Press, 1997. 
6. R.E. Palmer. The Liminality of Hermes and the Meaning of Hermeneutics // Proceedings of the Heraclitean Society. A Quarterly Report on Philosophy and Criticism of the Arts and Sciences, vol.5. - Michigan, 1980, p.4-11.

7. Тернер В. - Символ и ритуал М.: Главная редакция восточной литературы издательства «Наука», 1983. - 277 с.

8. Bollas Chr. The Shadow of the Object. Columbia University Press. 1989

9. Фусу Л.И. Кризисное состояние, переломное и лиминальное в политическом дискурсе / The crisis, the critical and the liminal in political discourse Eвразийский юридический журнал. 2018 (8):428-429m.

10. Фрейд 3. Психология масс и анализ человеческого «Я»/пер. с нем //ям Когана. СПб.: Издательская группа «Азбука-классика. - 2010.

11. Фрейд 3. Тотем и табу. Психология первобытной культуры и религии/Зигмунд Фрейд //Сиб.: Алтейя. - 2000.

$$
\text { ( Фусу Лариса Ивановна (florayy@mail.ru). }
$$

Журнал «Современная наука: актуальные проблемы теории и практики»

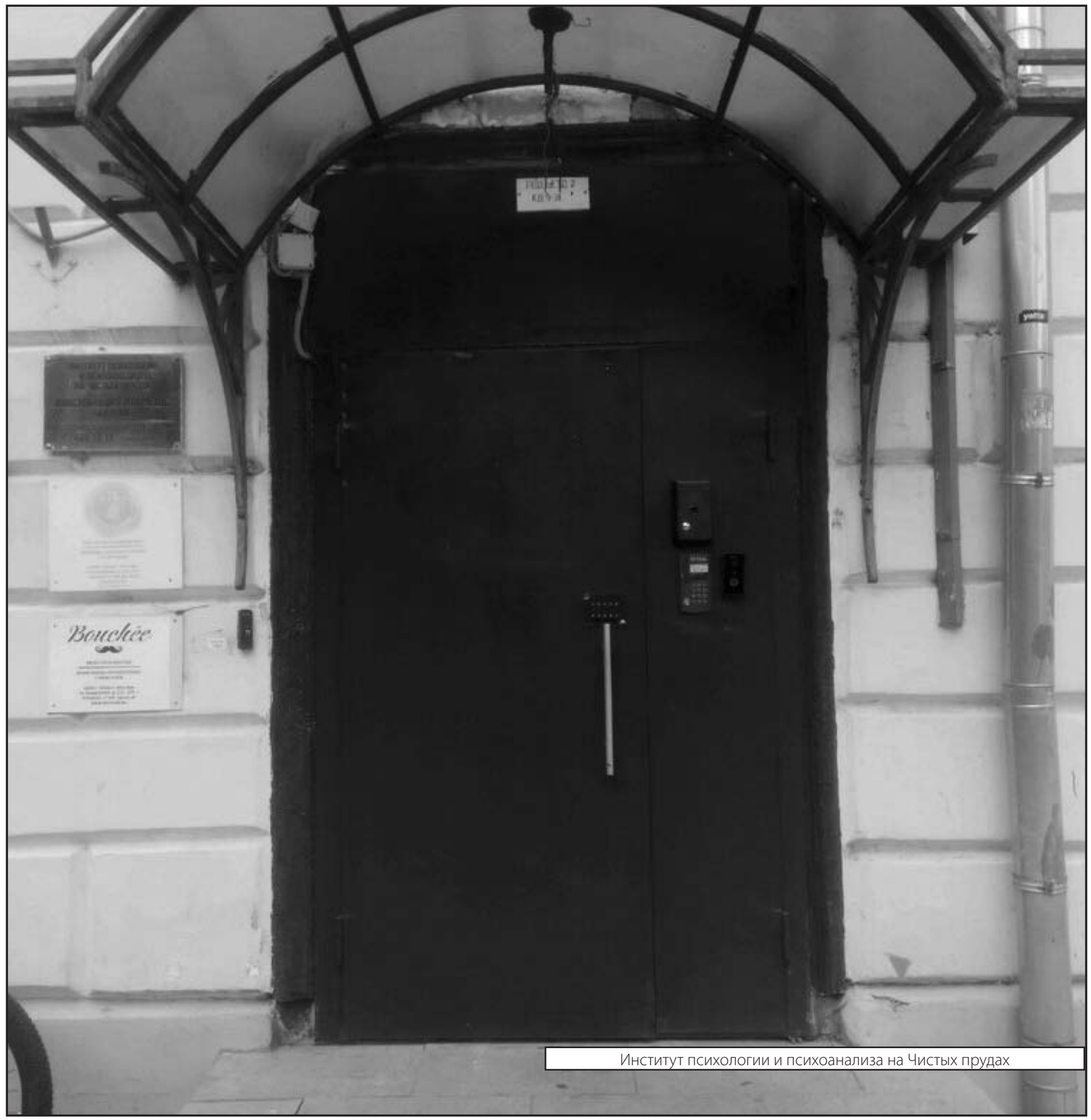

